\title{
Pengaruh Fitoremediasi Kangkung (Ipomea aquatika), apu-apu (Pistia stratiotes) dan Enceng Gondok (Eichornia crassipes) Terhadap Kualitas Air Kolam Budiaya Ikan Lele (Clarias sp)
}

\author{
Phytoremediation Effect of Ipomea Aquatika, Pistia stratiotes and \\ Eichornia crassipes on the Catfish (Clarias sp) aquaculture Quality
}

\author{
Erwin Prasetya Toepak ${ }^{1 *}$, Julian Tambunan ${ }^{2}$, Yunus Febrianto ${ }^{3}$, Ferry Purwanto ${ }^{1}$, Dominikus Niholan \\ Tukan ${ }^{1}$
}

\begin{abstract}
1Jurusan Kimia, Fakultas Matematika dan Ilmu Pengetahuan Alam, Universitas Palangkaraya
2Jurusan Biologi, Fakultas Matematika dan Ilmu Pengetahuan Alam, Universitas Palangkaraya

3Jurusan Fisika, Fakultas Matematika dan Ilmu Pengetahuan Alam, Universitas Palangkaraya
\end{abstract}

Alamatemail: toepakerwin@mipa.upr.ac.id

\begin{abstract}
Abstrak - Salah satu bahan pangan yang banyak dikonsumsi di Indonesia ialah ikan. Ikan mengandung kandungan protein yang tinggi dan memiliki kandungan lemak di bawah 5\% sehingga lebih sehat untuk dikonsumsi dibandingkan ayam. Salah satu jenis ikan yang berpotensi dibudidayakan adalah ikan lele (Clarias sp) karena mudah untuk dibudidayakan dan dapat tumbuh dalam waktu yang relatif cepat. Permasalahan yang timbul saat pembudidayaan ikan lele adalah turunnya kualitas air kolam karena adanya pencemaran yang berasal dari kotoran lele dan sisa pakan.Upaya pengelolaan limbah dapat dilakukan melalui fitoremediasi. Pada penelitian ini digunakan tumbuhan air yang sering dianggap sebagai gulma tetapi diketahui memiliki kemampuan fitoremediasi yakni enceng gondok (Eichornia crassipes), kangkung (Ipomea Aquatika), dan apu-apu (Pistia stratiotes). Berdasarkan hasil penelitian, diketahui bahwa ketiga tumbuhan air tersebut mampu menjaga kualitas air kolam dan meningkatkan sintasan ikan lele. Kata kunci: fitoremediasi, kangkung, eceng gondok, apu-apu, ikan lele

Abstract - One kind of food that is widely consumed in Indonesia is fish. Fish contain high protein content and have a fat content below 5\%, so it is healthier than chicken to consumed. One of fish that is potentially cultivated is catfish (Clarias sp). This kind of fish is easy to be cultivated and can grow in a relatively fast time. The problem that arises when raising catfish is the declining quality of pond water due to pollution from catfish droppings and leftover food. Efforts to manage waste can be done through phytoremediation. This study used water plants that are often considered as weeds but are known to have phytoremediation capabilities, videlicet water hyacinth (Eichornia crassipes), water spinach (Ipomea Aquatika), and apu-apu (Pistia stratiotes). Based on research results, it is known that the three aquatic plants are able to maintain the quality of pond water and increase the survival of catfish.
\end{abstract}

Keywords: phytoremediation, water spinach, water hyacinth, apu-apu, catfish

(C) 2020 Jurnal Jejaring Matematika dan Sains. This work is licensed under a $\underline{C C B Y-N C 4.0}$

\section{PENDAHULUAN}

Salah satu jenis ikan yang berpotensi dibudidayakan di Indonesia adalah ikan lele (Clarias $s p$ ). Ikan ini memiliki nilai ekonomis karena mudah untuk dipelihara, dapat tumbuh dengan cepat serta memiliki kandungan protein yang tinggi. Konsumsi ikan lele ini sendiri juga cukup besar. Kota Yogyakarta memiliki kebutuhan konsumsi untuk ikan lele hingga 30 ton per hari. Besarnya potensi yang dimiliki oleh ikan ini, maka banyak masyarakat yang membudidayakan ikan lele baik secara itensif maupun tradisional [1] [2].

Permasalahan yang timbul dalam budidaya ikan lele adalah adanya limbah, baik yang cair maupun yang padat. Limbah-limbah tersebut berasal dari kotoran lele dan sisa pakan yang tak terkonsumsi. Adanya Limbah pencemaran ini dapat mempengaruhi kualitas air habitat budidaya lele. Air yang tercemar dapat menyebabkan kekurangan oksigen, keracunan, dan timbulnya berbagai penyakit pada lele sehingga berpengaruh sehingga pada pertumbuhan dan tingkat mortalitas ikan lele. Hal ini perlu diantisipasi dan dikelola sebab dapat berpengaruh pada hasil panen ikan lele [3] [1] .

Pengelolaan limbah pada budidaya ikan lele dapat dilakukan dengan melakukan pergantian air kolam, hanya saja cara ini tidak efektif dan efesien. Upaya pengelolaan limbah untuk dapat meningkatkan kualitas air adalah melalui fitoremediasi. Melalui metode ini, tumbuhan air yang ada di kolam budidaya dapat menggunakan limbah hasil budidaya lele sebagai nutrien maupun diolah oleh tumbuhan tersebut menjadi senyawa yang tidak berbahaya [1]. 
Dalam penelitian ini, akan dilakukan analisis perbandingan fitoremediasi 3 tumbuhan akuatik yakni enceng gondok (Eichornia crassipes), kangkung air (Ipomea Aquatika), dan apu-apu (Pistia stratiotes) terhadap kualitas air pada pembudidayaan ikan lele. Ketiga tumbuhan tersebut diketahui sejak lama merupakan tumbuhan yang dapat melakukan proses fitoremediasi senyawa kimia. Melalui penelitian ini, diharapkan dapat memberikan informasi mengenai tumbuhan akuatik mana yang cocok untuk meningkatkan kualitas air pada pembudidayaan ikan lele.

\section{METODE PENELITIAN}

Bahan-bahan yang digunakan ialah tumbuhan air (eceng gondok, kangkung air dan apu-apu), bibit ikan lele, dan pakan ikan. Adapun model penelitian yang digunakan adalah simpel random design yang melibatkan uji t satu sampel untuk melihat beda nyata antara kolam kontrol dan kolam perlakuan. Kolam ikan lele dibangun di halaman belakang Fakultas MIPA Universitas Palangka Raya. Kolam ini dibuat dengan ukuran $1 \mathrm{~m}^{2}$ sebanyak 4 buah. Salah satu kolam dijadikan sebagai kolam kontrol di mana pada kolam tersebut tidak terdapat tumbuhan air. Ketiga kolam lainnya, masing-masing akan ditanami eceng gondok, kangkung air dan apu-apu. Pada masing-masing kolam dibiakkan 150 bibit ikan lele. Pengamatan terhadap tingkat sintasan dilakukan setiap hari.

\section{HASIL DAN PEMBAHASAN}

Tingkat sintasan atau survival rate (SR) dari ikan lele pada masing-masing kolam diamati setiap hari sesaat sebelum pemberian makan. Setiap hari dihitung jumlah ikan yang mati pada masing-masing kolam. Pengamatan terhadap jumlah ikan yang mati dilakukan selama 20 hari. Berdasarkan hasil observasi selama 20 hari, maka jumlah ikan lele yang hidup ditunjukkan pada Tabel 1.

Tabel 1. Sintasan Ikan Lele Pembiakkan 20 Hari

\begin{tabular}{clc}
\hline No & Kolam Perlakuan & $\begin{array}{c}\text { Jumlah Ikan yang } \\
\text { hidup }\end{array}$ \\
\hline 1 & Kontrol & 126 \\
2 & Kangkung & 135 \\
3 & Apu-apu & 127 \\
4 & Eceng Gondok & 135 \\
\hline
\end{tabular}

Berdasarkan Tabel 4.1 terlihat bahwa jumlah ikan hidup terendah teramati pada kolam kontrol atau yang tanpa perlakuan. Sementara itu, kolam dengan tumbuhan kangkung dan eceng gondok sama-sama memiliki jumlah ikan hidup terbanyak. Kelangsungan hidup ikan lele turut dipengaruhi oleh kualitas air kolam [1]. Kehadiran tumbuhan air seperti kangkung, eceng gondok maupun apu-apu diharapkan dapat meningkatkan kualitas air sehingga tingkat sintasan ikan lele meningkat. Perhitungan jumlah ikan lele yang hidup pada masingmasing kolam didasarkan pada seberapa banyak ikan yang mati. Adapun jumlah ikan yang hidup pada pembiakkan 20 hari dapat memberikan suatu informasi mengenai seberapa besar sintasan dari ikan lele pada masing-masing perlakuan

Adapun nilai dari SR itu sendiri dapat diukur dengan suatu persamaan matematis sederhana yakni [4] :

$$
S R=\frac{N t}{N 0} \times 100 \%
$$

Yang mana variabel pada persamaan tersebut menyatakan :

$\mathrm{Nt}$ adalah jumlah ikan yang berhasil hidup pada masingmasing kolam;

SR menyatakan nilai persentase sintasi ikan lele;

N0 itu sendiri adalah jumlah ikan pada mulanya di masing-masing kolam.

Berdasarkan persamaan 1, maka tingkat sintasan atau SR dapat dilihat pada Tabel 4.2

Tabel 2. Nilai SR pada Masing-Masing Kolam

\begin{tabular}{clc}
\hline No & \multicolumn{1}{c}{ Kolam Perlakuan } & SR (\%) \\
\hline 1 & Kontrol & 84 \\
2 & Kangkung & 90 \\
3 & Apu-apu & 84,7 \\
4 & Eceng Gondok & 90 \\
\hline
\end{tabular}

Nilai SR Tabel 1. berkesesuaian dengan Tabel 2. sehingga terlihat bahwa ikan lele yang dibiakkan selama 20 hari pada kolam kengkung dan eceng gondok menunjukkan tingkat sintasan yang baik yakni mencapai $100 \%$. Hal ini menunjukkan bahwa keberadaan tumbuhan kangkung dan eceng gondok dapat meningkatkan kelangsungan hidup ikan lele. Perbedaan nilai SR dari kolam kontrol dan apu-apu terlihat hanya berbeda 3,5\%. Pada kolam apu-apu sering ditemui tumbuhan yang mati sehingga hal ini diperkirakan mempengaruhi kualitas air.

Uji t terhadap data pada Tabel 1. dengan taraf kepercayaan $90 \%$ dilakukan untuk menganalisis lebih lanjut mengenai pengaruh agen fitoremediator terhadap kualitas air kolam. Apabila nila dari $t_{\text {hitung }}<t_{\text {tabel }}$ maka dapat diketahui bahwa tidak terdapat perbedaan nyata antara kolam kontrol dan kolam perlakuan [5]. Berdasarkan hasil uji t satu sampel terhadap data sintasan ikan lele, maka diperoleh nilai $\mathrm{t}_{\text {hitung }}>\mathrm{t}_{\text {tabel }}$ yang mengindikasikan bahwa terdapat beda nyata antara kolam kontrol dan kolam perlakuan. Hal ini menunjukkan bahwa terdapat pengaruh dari tumbuhan yang terdapat pada kolam perlakuan terhadap sintasan ikan lele.

Adapun data pada Gambar 1. menunjukkan bahwa hasil pengukuran $\mathrm{pH}$ hasil pembiakkan 20 hari menunjukkan bahwa kolam yang ditanami kangkung memiliki nilai $\mathrm{pH}$ yang masuk dalam rentang $\mathrm{pH}$ yang baik untuk agar ikan dapat tumbuh secara optimum dan mengurangi angka kematian. Adapun rentang $\mathrm{pH}$ yang baik untuk budidaya ikan lele adalah berkisar antara 6,58,5 [6]. Ikan lele masih dapat hidup pada $\mathrm{pH}$ pada nilai 4,5 [7], meskipun demikian tingkat sintasannya akan berkurang dan pertumbuhan optimum ikan akan terganggu. Hasil uji $\mathrm{t}$ terhadap data nilai $\mathrm{pH}$ menunjukkan bahwa nilai $t_{\text {hitung }}<t_{\text {tabel. }}$ Hal ini 
menunjukkan perlakuan kolam tidak berpengaruh nyata terhadap nilai $\mathrm{pH}$.

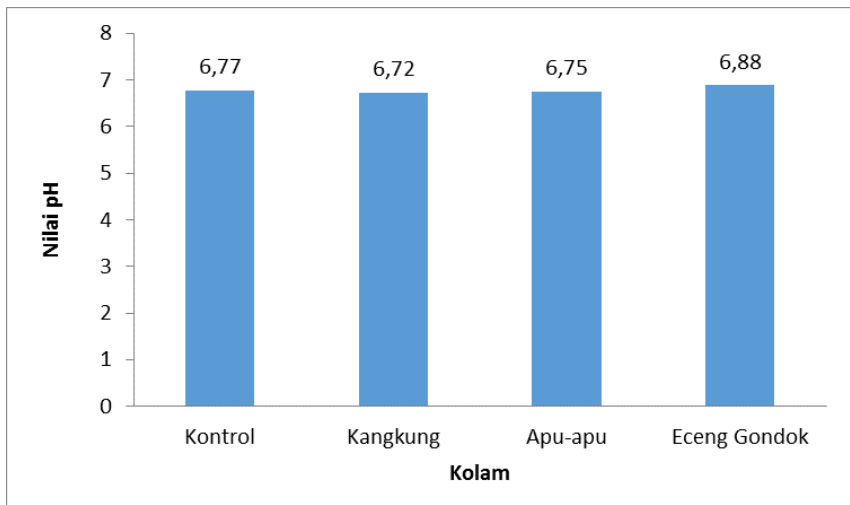

Gambar 1. Grafik Nilai pH Air Kolam 20 hari

Hasil pengukuran konsentrasi nitrit pada keempat kolam ditunjukkan pada Gambar 2. Konsetrasi nitrit pada masing-masing percobaan bernilai kurang dari 1 ppm yang menunjukkan bahwa kualitas air kolam sudah cukup baik untuk pembudidayaan ikan. Jika diamati pada Gambar 2, maka konsentrasi nitrit pada kolam kontrol lebih kecil dari kolom yang lainnya. Hal ini disebabkan karena konsentrasi nitrit dipengaruhi oleh akumulasi bahan organik yang berasal dari hasil metabolisme ikan yang ternitirifikasi maupun besarnya senyawa nitrat yang dapat diubah oleh bakteri menjadi nitrat [3] [8]. Pada kolam kontrol, sintasan ikan lebih rendah dibandingkan dengan kolam lainnya sehingga kadar nitrit yang terukur pun sedikit. Hasil analisis statistika berdasarkan uji t kadar nitrit antar kolam diketahui bahwa $t_{\text {hitung }}>t_{\text {tabel }}$.

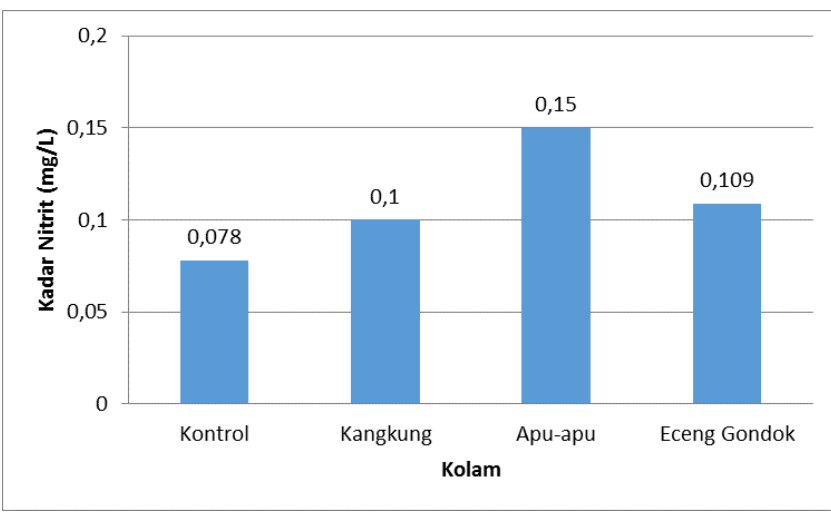

Gambar 2. Grafik Kadar Nitrit Air Kolam 20 hari

Pengukuran terhadap parameter fisik TSS (Total Suspended Solid) juga dilakukan terhadap masing-masing kolam. Hasil pengukuran ditunjukkan pada Gambar 3. Kadar TSS agar ikan lele kelas produksi dapat tumbuh dengan optimum ialah jika kadar TSS $<50 \mathrm{mg} / \mathrm{L}$. Jika dilihat pada Gambar 3, maka semua kolam memiiki nilai TSS yang lebih besar dari nilai optimum. Ikan masih dapat hidup tapi tidak dapat tumbuh dengan optimum. Tingginya kadar nilai TSS pada masing-masing kolam terjadinya karena masih banyaknya akumulasi sisa padatan yang berasal dari pakan yang tak termakan maupun hasil metabolisme ikan yang tidak direduksi oleh tumbuhan fotoremediasi yang ditanam [8] [9].

Air kolam dikatakan belum memenuhi mutu air kelas III jika nilai dari TSS $>400 \mathrm{mg} / \mathrm{L}$. Kolam kontrol dan kolam kangkung memiliki kadar TSS yang lebih besar dari $400 \mathrm{mg} / \mathrm{L}$. Hal ini menunjukkan bahwa air pada kedua kolam tersebut belum memenuhi baku mutu air yang dipersyaratkan [5] [10]. Ini juga mengindikasikan bahwa tumbuhan kamgkung kurang optimal dalam mereduksi kadar TSS dalam air. Berdasarkan hasil uji t terhadap data nilai TSS, maka diketahui bahwa $t_{\text {hitung }}<t_{\text {tabel }}$ sehingga tak ada perbedaan nyata antar kolam perlakuan.

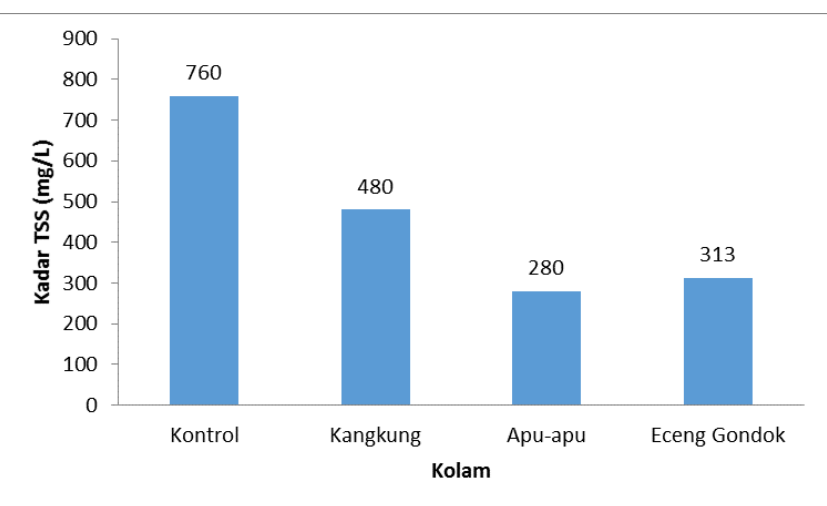

Gambar 3. Grafik Kadar TSS Pada Masing-Masing Air Kolam 20 hari

\section{SIMPULAN}

Kesimpulan yang dapat diambil dari observasi terhadap kolam ikan lele yang diberikan perlakukan yang berbeda selama 20 hari ialah bahwa kolam yang ditanami kangkung dan eceng gondok menunjukkan tingkat sintasan yang paling baik. Tingkat sintasan atau SR dari kolam yang ditanami kangkung dan eceng gondok mencapai $100 \%$ untuk masa pembiakkan 20 hari. Hasil pengujian terhadap kualitas air menunjukkan bahwa tumbuhan kangkung, apu-apu dan eceng gondok dapat memperbaiki kualitas air.

\section{UCAPAN TERIMA KASIH}

Terima kasih diucapkan kepada LPPM Universitas Palangkaraya atas bantuan dana dalam penyelenggaraan penelitian ini. Penelitian ini didanai dari DIPA PNBP Universitas Palangka Raya Tahun 2018 Nomor : 042.01.2.400956/2019 tanggal 20 Juni 2019 Sesuai dengan Kontrak Penelitian Nomor : 485/UN24.13/PL/2019

\section{REFERENSI}

[1] H. Effendi, B. A. Utomo, G. M. Darmawangsa, and R. E. Karo-Karo, "Fitoremediasi Limbah Budidaya Ikan Lele (Clarias sp.) Dengan Kangkung (Ipomoea aquatica) Dan Pakcoy (Brassica rapa Chinensis) Dalam Sistem Resirkulasi," Ecolab, vol. 9, no. 2, 2015.

[2] W. N. Muhammad and S. Andriyanto, "Manajemen Budidaya Ikan Lele Dumbo (Clarias gariepinus) Di Kampung Lele, Kabupaten Boyolali, Jawa Tengah," Media Akuakultur, vol. 8, no. 1, 2013. 
[3] A. A. F. Dhiba, S. Husain, and Ernawati, "Analisis Kualitas Air Pada Kolam Pendederan Ikan Lele Dumbo (Clarias gariepinus) Dengan Penambahan Tepung Daun Singkong (Manihot utillisima) Sebagai Pakan Buatan," Jurnal Pendidikan Teknologi Pertanian, vol. 5, pp. S131-S144, 2019.

[4] F. A. Rahmad, I. Suharman, and Adelina, "Effect of Fermented Water Hyacinth (Eichhornia crassipes) Meal Using A Cow Rumen Fluid in Diets on Growth of River Carp (Leptobarbus hoevenii) Fingerling," J. Online Mhs. Fak. Perikan. dan Ilmu Kelaut. Univ. Riau, 2017.

[5] Nurhidayah, D. Sofarini, and Yunandar, "Fitoremediasi Tumbuhan Air Kiambang (Salvinia molesta) Purun Tikus (Eleocharis dulcis ) Dan Perupuk (Phragmites karka) Sebagai Alternatif Pengolahan Limbah Cair Karet," EnviroScienteae, vol. 10, pp. 18-26, 2014.

[6] F. A. Pratama, N. Afiati, and A. Djunaedi, "Kondisi Kualitas Air Kolam Budidaya Dengan Penggunaan Probiotik Dan Tanpa Probiotik Terhadap Pertumbuhan Ikan Lele Sangkuriang (Clarias sp) Di Cirebon, Jawa Barat," DIPONEGORO JOURNAL OF MAQUARES MANAGEMENT OF AQUATIC RESOURCES, vol. 5, no. 1, pp. 38-45, 2016.

[7] K. Marimuthu, H. Palaniandy, and Z. A. Muchlisin, "Effect of different water $\mathrm{pH}$ on hatching and survival rates of African catfish Clarias gariepinus (Pisces: Clariidae)," Aceh Journal of Animal Science, vol. 4, no. 2, pp. 80-88, 2019.

[8] M. L. Sitohang, M. Fitrani, and D. Jubaedah, "Pemanfaatan Campuran Buah Nanas, Air Cucian Beras, Dan Gula Sebagai Sumber Karbon Pada Media Pemeliharaan Ikan Lele ( Clarias sp ) Dengan Sistem Bioflok," JARI, vol. 6, no. 1, pp. 51-64, Jul. 2018, doi: 10.36706/jari.v6i1.7149.

[9] H. Ahmad and R. Adiningsih, "Efektivitas Metode Fitoremediasi Menggunakan Tanaman Eceng Gondok dan Kangkung Air dalam Menurunkan Kadar BOD dan TSS pada Limbah Cair Industri Tahu," farmasetis, vol. 8, no. 2, pp. 31-38, Nov. 2019, doi: 10.32583/farmasetis.v8i2.599.

[10] M. Kamelia and N. Widiani, "Analisis Perbedaan Jumlah Bakteri Pada Ikan Nila (Oreochromis niloticus) Budidaya Analysis of the Bacteria Difference in Tilapia (Oreochromis niloticus) Cultivation," vol. 11 , no. 2 , p. 7. 